\title{
Chloramphenicol Acetyltransferase-independent Chloramphenicol Resistance in Streptomyces coelicolor A3(2)
}

\author{
By R. F. FREEMAN, M. J. BIBB AND D. A. HOPWOOD, \\ John Innes Institute, Colney Lane, Norwich $\mathrm{NR}_{4}{ }_{7} \mathrm{UH}$
}

(Received II August 1976)

\begin{abstract}
SUMM ARY
Streptomyces coelicolor $\mathrm{A3}(2)$ and $S$. lividans 66 , which lack chloramphenicol acetyltransferase, gave rise to chloramphenicol-sensitive $\left(\mathrm{Cml}^{\mathrm{s}}\right)$ variants spontaneously at frequencies of 0.5 to $2 \%$. The fertility type of $S$. coelicolor in respect of the SCPI plasmid (SCPI ${ }^{+}, \mathrm{SCP}_{1}^{-}$or NF) had no effect on chloramphenicol sensitivity or on the frequency at which $\mathrm{Cml}^{\mathrm{s}}$ variants arose.

$\mathrm{Cml}^{\mathrm{S}}$ isolates spontaneously reverted to $\mathrm{Cml}^{\mathrm{R}}$ at frequencies one to three orders of magnitude lower than the frequency with which $\mathrm{Cml}^{\mathrm{s}}$ strains arose from $\mathrm{Cml}^{\mathrm{R}}$. $\mathrm{Cml}^{\mathrm{R}}$ revertants obtained spontaneously from $\mathrm{Cml}^{\mathrm{s}}$ clones again produced $\mathrm{Cml}^{\mathrm{S}}$ isolates at the normal frequency of several per cent. Therefore, $\mathrm{Cml}^{\mathrm{s}}$ and $\mathrm{Cml}^{\mathrm{R}}$ are reversible phenotypes.

In crosses between marked $\mathrm{Cml}^{\mathrm{R}}$ and $\mathrm{Cml}^{\mathrm{s}} S$. coelicolor strains, transfer of chloramphenicol resistance into the sensitive strain apparently occurred independently of chromosomal recombination. Mapping experiments excluded the possibility that segregation of a chromosomal locus determines $\mathrm{Cml}^{\mathrm{R}}$ versus $\mathrm{Cm}^{\mathrm{S}}$ phenotype. In crosses between $\mathrm{SCPI}^{-}$strains, fertility was not significantly different in $\mathrm{Cml}^{\mathrm{R}} \times \mathrm{Cml}^{\mathrm{s}}, \mathrm{Cml}^{\mathrm{R}} \times \mathrm{Cml}^{\mathrm{R}}$ and $\mathrm{Cml}^{\mathrm{s}} \times \mathrm{Cml}^{\mathrm{s}}$ combinations.

Covalently closed circular DNA from $\mathrm{Cml}^{\mathrm{s}}$ and $\mathrm{Cml}^{\mathrm{R}}$ strains of $S$. coelicolor was indistinguishable in molecular weight and restriction endonuclease cleavage pattern.

It is suggested that chloramphenicol resistance in S. coelicolor A3(2) is affected by some kind of transposable genetic element that may be capable of extrachromosomal existence.
\end{abstract}

\section{INTRODUCTION}

The production of antibiotics and resistance to them in streptomycetes is sometimes controlled by plasmids. The SCPI plasmid of Streptomyces coelicolor A3(2) determines resistance to methylenomycin $\mathrm{A}$, as well as its production (Vivian, 197I ; Kirby, Wright \& Hopwood, 1975; Wright \& Hopwood, 1976), and a plasmid is involved in resistance to oxytetracycline in Streptomyces rimosus (Boronin \& Sadovnikova, 1972). Since plasmiddetermined resistance to antibiotics in streptomycetes is relevant to the theory that the resistance genes now occurring on $\mathbf{R}$ factors in the Enterobacteriaceae might have originated in the antibiotic-producing organisms (Benveniste \& Davies, 1973), we set out to identify other possible examples of extra-chromosomal determination of antibiotic resistance in the genus Streptomyces, whose members produce over $60 \%$ of known antibiotics (Bérdy, 1974). One approach was to test the intrinsic resistance of a collection of wild-type streptomycetes to a variety of antibiotics (Freeman, 1976), and to select as potential candidates for more detailed investigation those strains that were more resistant to a particular antibiotic than were the majority of the collection.

Another approach was to test for the occurrence of known antibiotic-inactivating enzymes in streptomycetes and to study the genetics of their production in appropriate strains, 
Shaw \& Hopwood (1976) found the enzyme chloramphenicol acetyltransferase in several streptomycetes and its genetic determination is being studied in one of them, Streptomyces acrimycini (D. A. Hopwood \& H. M. Wright, unpublished results). Streptomyces coelicolor A3(2), the strain in which extensive genetical investigations have been carried out (Hopwood et al. 1973), does not have the acetylating enzyme. However, it was the most chloramphenicol-resistant strain studied by Shaw \& Hopwood (1976), except for Streptomyces venezuelae, the chloramphenicol producer. Thus the two approaches converged on $S$. coelicolor A3(2). The present paper shows that chloramphenicol resistance is indeed influenced by some kind of extra-chromosomal element, perhaps of a novel kind, in this strain. A preliminary report of these results has been made (Freeman, Bibb \& Hopwood, I976) and we have also become aware of an independent investigation which seems to be in part similar to our own (G. Sermonti, personal communication).

\section{METHODS}

Strains. The cultures were derivatives of S. coelicolor A3(2) and S. lividans 66 (Lomovskaya et al., 1972); they are listed in Table I.

Cultural and genetic methods. Minimal (MM) and complete (CM) media and general cultural and genetic techniques were those described by Hopwood (I967). Ultraviolet (u.v.) irradiation was done as described by Harold \& Hopwood (1970); survival was about I \%.

Isolation of chloramphenicol-sensitive strains. Streptomyces coelicolor A3(2) colonies grew almost without inhibition when replicated to supplemented MM containing $16 \mu \mathrm{g}$ chloramphenicol ml-1 (Cambrian Chemicals, Croydon). Streptomyces lividans 66 replicated satisfactorily on to media containing $8 \mu \mathrm{g}$ chloramphenicol ml-1. Sensitive isolates $\left(\mathrm{Cml}^{\mathrm{s}}\right)$ were obtained, both spontaneously and after u.v. irradiation, by plating on suitably supplemented MM at a dilution to give well separated colonies. These were replicated when they were well sporulated to supplemented MM plates containing the appropriate concentration of chloramphenicol. Colonies that failed to replicate were streaked and re-tested; most were confirmed as $\mathrm{Cml}^{\mathrm{s}}$.

Selection for chloramphenicol-resistant isolates. Chloramphenicol-resistant $\left(\mathrm{Cml}^{\mathrm{R}}\right)$ spores were selected from an excess of $\mathrm{Cml}^{s}$ by plating on supplemented $\mathrm{MM}$ containing $8 \mu \mathrm{g}$ chloramphenicol ml-1. $\mathrm{Cml}^{\mathrm{R}}$ spores produced discrete colonies after 3 to 4 days incubation, whereas the $\mathrm{Cml}^{\mathrm{s}}$ spores were largely inhibited.

Antibiotic-sensitivity spectrum. Single colonies were used to inoculate $25 \mathrm{ml}$ medium B (Okanishi, Ohta \& Umezawa, 1970) in $250 \mathrm{ml}$ conical flasks, each containing a coiled stainless-steel spring to aid growth dispersal and aeration. The cultures were grown on an orbital shaker at $30^{\circ} \mathrm{C}$ for $40 \mathrm{~h}$. The mycelium was allowed to settle and $\mathrm{I} \cdot 5 \mathrm{ml}$ was cooled in ice and sonicated for $\mathrm{I} 5 \mathrm{~min}$ (in $\mathrm{I} 5 \mathrm{~s}$ bursts) at setting 3 on a Soniprobe with a microtip (type $7530 \mathrm{~A}$; Dawe Instruments, London). The supernatant from this preparation ( $0.1 \mathrm{ml})$ was spread on plates of supplemented MM $(25 \mathrm{ml})$, in which glycerol (1 \%, v/v) was substituted for glucose as carbon source, and dried in a horizontal laminar-flow cabinet (Slee, London) to remove surface moisture. Each plate then received three antibiotic test discs (Mast Laboratories, Liverpool), spaced equidistantly, and was incubated for 2 days before the diameters of the inhibition zones were measured.

Isolation and characterization of covalently closed circular (c.c.c.) DNA. ${ }^{3} \mathrm{H}$-labelled c.c.c. DNA was isolated by dye-buoyant centrifugation from mycelium grown in a Casamino acids/glycine medium supplemented with $\left[{ }^{3} \mathrm{H}\right]$ thymidine essentially by the method of Schrempf et al. (1975) and Bibb, Freeman \& Hopwood (unpublished). The labelled plasmid 
Table I. Strains of S. coelicolor A3(2) and S. lividans 66

Strain

no.

Genotype

$\begin{array}{cc}\text { Fertility } & \text { Cml } \\ \text { type } & \text { phenotype }\end{array}$

S. coelicolor

\begin{tabular}{|c|c|c|c|}
\hline A3(2) & Wild type & $\mathrm{SCP}^{+}$ & $\mathbf{R}$ \\
\hline $\mathrm{A} 3(2) / I^{*}$ & Wild type & $\mathrm{SCPI}^{+}$ & $\mathbf{s}$ \\
\hline 104 & hisAI uraAI strAI & $\mathrm{SCPI}^{+}$ & $\mathbf{R}$ \\
\hline A332 & pheAI & NF & $\mathbf{R}$ \\
\hline A332/I* & pheAI & NF & $\mathbf{s}$ \\
\hline A332/3* & pheAI & NF & $\mathbf{s}$ \\
\hline $\mathrm{A} 332 / 5^{*}$ & pheAI & NF & $\mathbf{s}$ \\
\hline A700 & pro $A I \arg A I$ cysDI8 & $\mathrm{SCPI}^{-}$ & $\mathbf{R}$ \\
\hline A700/6* & proAI $\arg A I$ cysDI8 & $\mathrm{SCP}_{I^{-}}$ & $\mathbf{s}$ \\
\hline 1098 & pheAr & $\mathrm{SCPI}^{-}$ & $\mathbf{R}$ \\
\hline $\log 8 / 1^{*}$ & pheAI & $\mathrm{SCPI}^{-}$ & $\mathbf{s}$ \\
\hline $1098 / 3^{*}$ & pheAI & $\mathrm{SCPr}^{-}$ & $\mathbf{s}$ \\
\hline 1190 & his $A I$ uraAI strAI & $\mathrm{SCPI}^{-}$ & $\mathbf{R}$ \\
\hline $1190 / I^{*}$ & hisAI uraAI strAI & $\mathrm{SCP}^{-}$ & $\mathbf{s}$ \\
\hline I $190 / 2^{*}$ & hisAI uraAI strAI & $\mathrm{SCPI}^{-}$ & $\mathbf{s}$ \\
\hline I $190 / 4^{*}$ & hisAI uraAI strAI & $\mathrm{SCPI}^{-}$ & $\mathbf{s}$ \\
\hline I 258 & $\begin{array}{l}\text { proAI argAI hisC9 } \\
\text { cysDI8 uraAI strAI }\end{array}$ & NF & $\mathbf{R}$ \\
\hline $2552 \dagger$ & cys DI8 str $A I$ & $\mathrm{NF}$ & $\mathbf{s}$ \\
\hline \multicolumn{4}{|c|}{ S. lividans 66} \\
\hline I 697 & $c y s-3$ & - & $\mathbf{R}$ \\
\hline I 697/I* & $c y s-3$ & 一 & $\mathbf{s}$ \\
\hline
\end{tabular}

DNA was characterized by sedimentation in 5 to $20 \%$ neutral and alkaline sucrose gradients, five-drop fractions being collected from the bottom of the tube and assayed for trichloroacetic acid precipitable radioactivity. Labelled ColEI DNA was used as a standard, having sedimentation values of $23 \mathrm{~S}$ and $48 \mathrm{~S}$ in neutral and alkaline conditions respectively. Unlabelled c.c.c. DNA was prepared by a large-scale method (unpublished) using PEG 6000 precipitation (Humphreys, Willshaw \& Anderson, 1975). The unlabelled plasmid DNA was characterized by digestion with SalI restriction endonuclease prepared by the method of Chater \& Wilde (1976) and the digestion products were analysed by $\mathrm{I} \cdot 4 \%$ agarose gel electrophoresis (unpublished). A HindIII digest of phage $\lambda$ DNA was used as a standard. The SalI endonuclease and phage $\lambda$ DNA were kindly donated by Dr K. F. Chater.

\section{RESULTS}

\section{Isolation and reversion of $\mathrm{Cml}^{\mathrm{s}}$ clones}

Frequency of occurrence of $\mathrm{Cml}^{\mathrm{s}}$ isolates. Streptomyces coelicolor A3(2) and S. lividans 66 tolerate up to about 20 and $\mathrm{I} 0 \mu \mathrm{g}$ chloramphenicol $\mathrm{ml}^{-1}$ respectively in MM (Shaw \& Hopwood, 1976). We chose $\mathrm{I} 6$ and $8 \mu \mathrm{g} \mathrm{ml}^{-1}$ respectively as concentrations on which to seek sensitive derivatives. Both strains yielded derivatives at least Io-fold more sensitive $\left(\mathrm{Cml}^{\mathrm{s}}\right)$ than the parent. In the case of $S$. coelicolor A3(2), similar frequencies were observed for $\mathrm{SCPI}^{+}, \mathrm{NF}$ and $\mathrm{SCPI}^{-}$derivatives. The spontaneous frequency was usually about $0.5 \%$, and this usually increased to up to $5 \%$ after u.v. irradiation (Table $2 a$ ). Many of the $\mathrm{Cml}^{\mathrm{s}}$ variants resembled the $\mathrm{Cml}^{\mathrm{R}}$ parent cultures in appearance, but some sporulated less well than the parent. 
Table 2. Isolation of chloramphenicol-sensitive $\left(\mathrm{Cml}^{\mathrm{B}}\right)$ and chloramphenicol-resistant $\left(\mathrm{Cml}^{\mathrm{R}}\right)$ clones

(a) Isolation of $\mathrm{Cml}^{\mathrm{s}}$ strains from $\mathrm{Cml}^{\mathrm{R}}$ parents

$\begin{array}{lccr}\text { Strain } & \text { Treatment } & \begin{array}{c}\text { Total no. } \\ \text { of colonies }\end{array} & \begin{array}{c}\mathrm{Cml}^{\mathrm{s}} \\ \text { isolates }\end{array} \\ \text { S. coelicolor } & & & \\ \text { A3(2) } & \text { Control } & 687 & 0.4 \\ & \text { u.v. } & 3000^{*} & 0.2 \\ \text { A332 } & \text { Control } & 71 \mathrm{I} & 2 \cdot 1 \\ & \text { u.v. } & 172 \mathrm{I} & 4.4 \\ \text { I098 } & \text { Control } & 2066 & 0.5 \\ & \text { u.v. } & 3475 & 2 \cdot 6 \\ \text { I190 } & \text { Control } & 40 & <0.4 \\ & \text { u.v. } & 287 & 4.5 \\ \text { S. lividans } & \text { Control } & 169 & <0.6 \\ \text { I697 } & \text { u.v. } & 638 & 5.2 \\ & \text { Control } & 507 & 0.4 \\ & \text { u.v. } & 902 & 1 \cdot 4\end{array}$

* Crowded plates.

(b) Isolation of $\mathrm{Cml}^{\mathrm{R}}$ revertants from $\mathrm{Cml}^{\mathrm{S}}$ strains

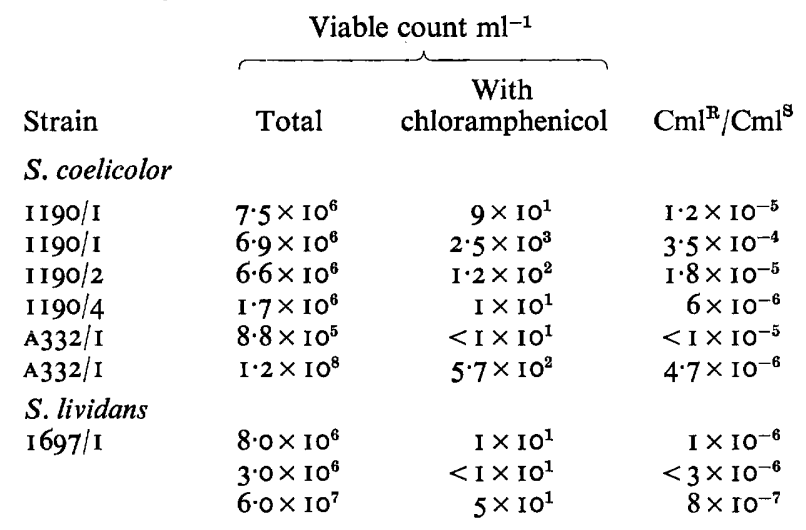

(c) Isolation of $\mathrm{Cml}^{\mathrm{S}}$ strains from $\mathrm{Cml}^{\mathrm{R}}$ revertants

$\begin{array}{lccc}\text { Strain } & \text { Treatment } & \begin{array}{c}\text { Total no. } \\ \text { of colonies }\end{array} & \begin{array}{c}\mathrm{Cm}^{\mathrm{S}} \\ \text { isolates }(\%)\end{array} \\ \text { S. coelicolor } & & & \\ \text { I190/I-R6 } & \text { Control } & 612 & 3.6 \\ & \text { u.v. } & 650 & 3 \cdot 7 \\ \text { I 190/I-R8 } & \text { Control } & 52 \mathrm{I} & 5 \cdot 0 \\ \text { A700/6-R4 } & \text { u.v. } & 94 \mathrm{I} & 3 \cdot \mathrm{I}\end{array}$

Isolation of $\mathrm{Cml}^{\mathrm{R}}$ revertants from $\mathrm{Cml}^{\mathrm{s}}$ strains. $\mathrm{Cml}^{\mathrm{s}}$ isolates reverted spontaneously to their original $\mathrm{Cml}^{\mathrm{R}}$ phenotype, but at a lower frequency than that of the origin of $\mathrm{Cml}$ from $\mathrm{Cml}^{\mathrm{R}}$-between one and three orders of magnitude lower for $S$. coelicolor and three to four orders of magnitude lower for $S$. lividans (Table $2 b$ ).

$R$ e-isolation of $\mathrm{Cml}^{\mathrm{S}}$ strains from $\mathrm{Cml}^{\mathrm{R}}$ revertants. Streptomyces coelicolor $\mathrm{Cml}^{\mathrm{R}}$ rever tants, obtained spontaneously from $\mathrm{Cml}^{\mathrm{s}}$ isolates, were tested for their ability to give rise again to the $\mathrm{Cml}^{\mathrm{s}}$ phenotype. Three $\mathrm{Cml}^{\mathrm{R}}$ revertants from two $\mathrm{SCPI}^{-} \mathrm{Cml}^{\mathrm{s}}$ isolates were 
Table 3. Sensitivity of S. coelicolor $\mathrm{Cml}^{\mathrm{R}}$ and $\mathrm{Cml}^{\mathrm{s}}$ strains to various antibiotics and antimicrobial drugs

Results are given as diameters $(\mathrm{mm})$ of zones of inhibition after 2 days incubation

\begin{tabular}{|c|c|c|c|c|c|c|c|c|c|}
\hline & & & $\mathrm{PI}^{+}$ & & NF & & & $\mathrm{SCP}_{1}$ & \\
\hline & Strain & A3(2) & $\mathrm{A} 3(2) / \mathrm{I}$ & A332 & A332/I & A332/3 & 1098 & I098/I & $1098 / 3$ \\
\hline $\mathrm{Cml} \mathrm{ph}$ & lenotype & $\ldots$ & S & $\mathbf{R}$ & $\mathbf{S}$ & $\mathbf{S}$ & $\mathbf{R}$ & S & $\mathbf{S}$ \\
\hline $\begin{array}{l}\text { Antimicrobial } \\
\text { agent }\end{array}$ & $\begin{array}{r}\text { Concn } \\
(\mu \mathrm{g} / \text { disc })\end{array}$ & & & & & & & & \\
\hline Streptomycin & IO & 40 & c. 40 & 38 & 34 & 34 & 40 & c. 44 & 40 \\
\hline Grentamicin & 2 & 20 & c. 28 & $2 I$ & 22 & 22 & 23 & 45 & 26 \\
\hline Kanamycin & 30 & 46 & c. 50 & 44 & 40 & 40 & 44 & 44 & $4 \mathrm{I}$ \\
\hline Erythromycin & 5 & 18 & c. I 5 & c. I4 & I6 & I 6 & 17 & 15 & NT \\
\hline Neomycin & 10 & 20 & 26 & 20 & 19 & 23 & 22 & 23 & 26 \\
\hline Novobiocin & 5 & $\mathbf{R}$ & $\mathbf{R}$ & $\mathbf{R}$ & $\mathbf{R}$ & $R$ & $\mathbf{R}$ & $\mathbf{R}$ & $\mathbf{R}$ \\
\hline Penicillin G & 4 & $\mathbf{R}$ & $\mathbf{R}$ & $\mathbf{R}$ & $\mathbf{R}$ & $\mathbf{R}$ & $\mathbf{R}$ & $\mathbf{R}$ & $\mathbf{R}$ \\
\hline Ampicillin & 10 & $\mathbf{R}$ & $\mathbf{R}$ & $\mathbf{R}$ & $\mathbf{R}$ & $\mathbf{R}$ & $\mathbf{R}$ & $\mathbf{R}$ & $\mathbf{R}$ \\
\hline Cephaloridine & 25 & $\mathbf{R}$ & $\mathbf{R}$ & $\mathbf{R}$ & $\mathbf{R}$ & $\mathbf{R}$ & $\mathbf{R}$ & $\mathbf{R}$ & $\mathbf{R}$ \\
\hline Tetracycline & 25 & $\mathbf{R}$ & $\mathbf{R}$ & $\mathbf{R}$ & $\mathbf{R}$ & $\mathrm{R}$ & $\mathbf{R}$ & $\mathrm{R}$ & $\mathbf{R}$ \\
\hline Sulphafurazole & 200 & c. 44 & c. 45 & 45 & c. 44 & 45 & c. 40 & c. 44 & c. 40 \\
\hline Bacitracin & 8 & c. I3 & c. I 5 & NT & 16 & 16 & $c$. I I & I4 & c. 12 \\
\hline Colistin $\mathrm{SO}_{4}$ & 25 & 15 & 18 & 17 & 18 & 16 & 19 & 16 & 16 \\
\hline Nalidixic acid & 30 & $\mathbf{R}$ & $\mathbf{R}$ & $\mathbf{R}$ & $\mathbf{R}$ & $\mathbf{R}$ & $\mathbf{R}$ & $\mathbf{R}$ & $\mathbf{R}$ \\
\hline Trimethoprim & $2 \cdot 5$ & $\mathbf{R}$ & $\mathbf{R}$ & $\mathbf{R}$ & $\mathbf{R}$ & $\mathbf{R}$ & $\mathbf{R}$ & $\mathbf{R}$ & $\mathbf{R}$ \\
\hline Polymyxin B & 100 & 14 & 14 & 12 & I4 & 13 & 14 & 15 & 13 \\
\hline Rifamycin & 30 & $\mathbf{R}$ & $\mathbf{R}$ & $\mathbf{R}$ & $\mathbf{R}$ & $\mathbf{R}$ & $\mathbf{R}$ & $\mathbf{R}$ & $\mathbf{R}$ \\
\hline Chloramphenicol & 25 & c. II & c. 29 & $c .9$ & $3 I$ & 31 & c. 10 & c. 20 & c. 20 \\
\hline
\end{tabular}

R, Resistant : no discernible zone. NT, Not tested.

studied (Table $2 c$ ). All three revertants produced $\mathrm{Cm}^{\mathrm{s}}$ isolates at a frequency of up to $5 \%$ of the total population. The morphology of these $\mathrm{Cm}^{\mathrm{s}}$ strains was indistinguishable from that of $\mathrm{Cml}^{\mathrm{s}}$ strains obtained from the original $\mathrm{Cml}^{\mathrm{R}}$ parents.

Test for occurrence of additional nutritional requirements in $\mathrm{Cml}^{\mathrm{R}}$ revertants

To test the possibility that mutations elsewhere in the genome might have been induced on reversion of $\mathrm{Cm}^{\mathrm{s}}$ to $\mathrm{Cml}^{\mathrm{R}}$ as in the case of excision and re-insertion of known transposable elements (Kleckner et al., 1975), auxotrophic mutations were sought by plating spores from strain I I $90 / \mathrm{I}$ on $\mathrm{CM}$ containing $8 \mu \mathrm{g}$ chloramphenicol $\mathrm{ml}^{-1}$ and replicating the resulting $\mathrm{Cm}^{\mathrm{R}}$ revertants to $\mathrm{MM}$ supplemented with histidine and uracil, the nutritional requirements of strain II $90 / \mathrm{I}$. Of the $\mathrm{I} I 86 \mathrm{Cml}^{\mathrm{R}}$ revertants tested, none displayed any additional nutritional requirement.

\section{Sensitivity spectrum of $S$. coelicolor $\mathrm{Cml}^{\mathrm{s}}$ and $\mathrm{Cml}^{\mathrm{R}}$ phenotypes to antibiotics and other antimicrobial agents}

The sensitivity spectra of one $\mathrm{Cml}^{\mathrm{s}}$ isolate from $\mathrm{SCPI}^{+}$strain $\mathrm{A3}(2)$, two from $\mathrm{NF}$ strain A332 and two from $\mathrm{SCPI}^{-}$strain 1098 were examined. There were no significant differences in sensitivity of $\mathrm{Cml}^{\mathrm{R}}$ and $\mathrm{Cml}^{\mathrm{s}}$ strains to any of the antimicrobial agents tested, except for chloramphenicol (Table 3).

\section{Transfer of the $\mathrm{Cml}^{\mathrm{R}}$ character, and fertility of crosses involving $\mathrm{Cml}^{\mathrm{s}}$ variants}

Crosses were made between $\mathrm{Cml}^{\mathrm{s}} \mathrm{SCPI}^{-}$strains and either $\mathrm{Cml}^{\mathrm{R}} \mathrm{SCPI}^{-}$or $\mathrm{Cml}^{\mathrm{R}} \mathrm{SCPI}^{+}$ strains to measure the transfer frequency of the $\mathrm{Cml}^{\mathrm{R}}$ character into $\mathrm{Cml}^{\mathrm{s}}$ genotypes and 
Table 4. Transfer of the $\mathrm{Cml}^{\mathrm{R}}$ character and fertility of crosses of different $\mathrm{Cml}$ status

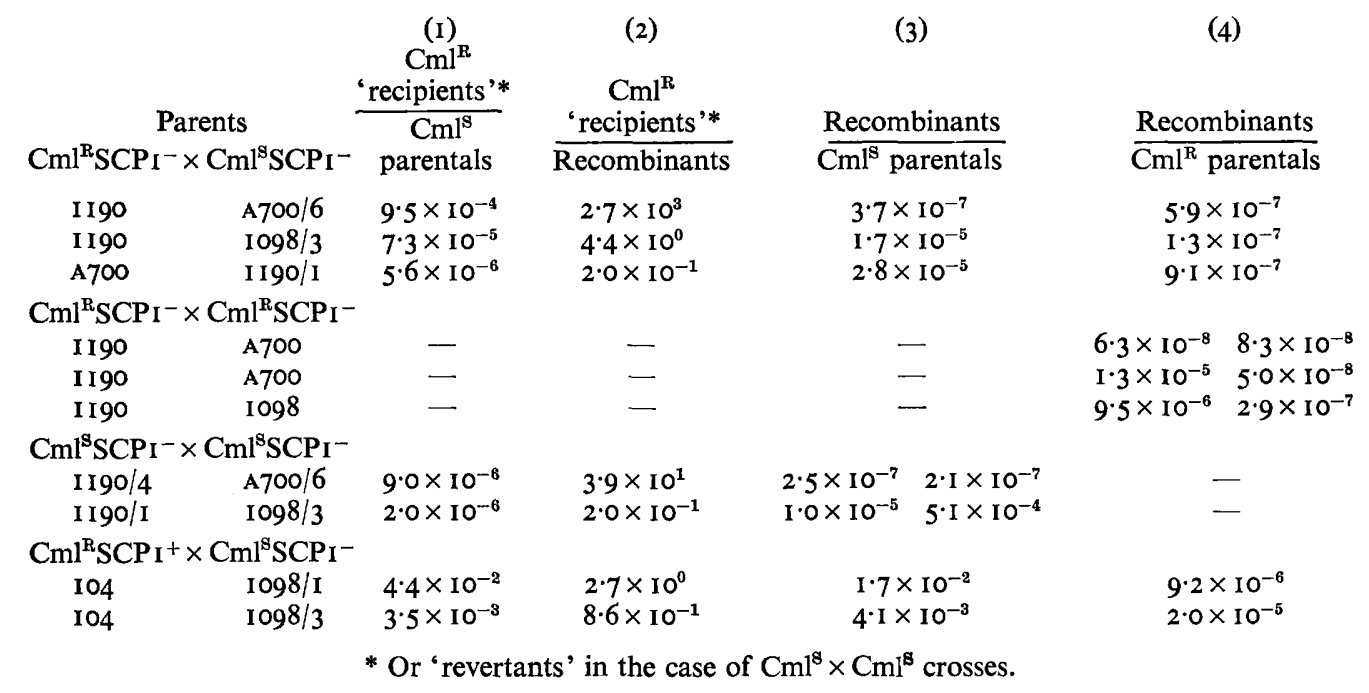

to compare it with the chromosomal recombination frequency (fertility) in order to detect any 'infectious' transfer of $\mathrm{Cm}^{\mathrm{R}}$ independent of chromosomal markers. The fertility of such crosses was also compared with those of $\mathrm{Cm}^{\mathrm{s}} \mathrm{SCPI}^{-} \times \mathrm{Cml}^{\mathrm{s}} \mathrm{SCPI}^{-}$and $\mathrm{Cml}^{\mathrm{R}} \mathrm{SCPI}^{-} \times$ $\mathrm{Cml}^{\mathrm{R}} \mathrm{SCPI}^{-}$crosses to detect any influence on fertility of $\mathrm{Cml}^{\mathrm{R}}$ versus $\mathrm{Cml}^{\mathrm{s}}$ status. The crosses were plated on selective media to recover each parental phenotype and on one or two media selecting recombinants. In addition, crosses involving $\mathrm{Cml}^{\mathrm{s}}$ strains were plated to recover a $\mathrm{Cml}^{\mathbb{R}}$ version of the $\mathrm{Cml}^{\mathrm{s}}$ parental phenotype(s): $\mathrm{Cml}^{\mathrm{R}}$ 'recipients', or 'revertants' in the case of $\mathrm{Cml}^{\mathrm{s}} \times \mathrm{Cml}^{\mathrm{s}}$ crosses. Four ratios were calculated (Table 4): (I) $\mathrm{Cml}^{\mathrm{R}}$ 'recipients' or 'revertants' $/ \mathrm{Cml}^{\mathrm{s}}$ parentals (an average of the parents when both were $\mathrm{Cml}^{\mathrm{s}}$ ); (2) Cml $\mathrm{Cm}^{\mathrm{R}}$ 'recipients' or 'revertants'/chromosomal recombinants; (3) chromosomal recombinants $/ \mathrm{Cml}^{\mathrm{s}}$ parentals; (4) chromosomal recombinants $/ \mathrm{Cml}^{\mathrm{R}}$ parentals. Calculation (I) measured transfer of $\mathrm{Cml}^{\mathrm{R}}$, (2) compared it with fertility and (3) and (4) measured fertility. The recombination frequencies for different selections in the same cross differed by a factor of only two or three and a single selection, for $\mathrm{His}^{+} \mathrm{Str}^{\mathrm{R}}$ throughout, is reported.

The main problem in evaluating the data concerns the varying relative yields of the two parental phenotypes from the same cross. Ideally, only well 'balanced' crosses would be considered, and examples of these could be found provided that only $\mathrm{SCPI}^{-}$strains were used [compare columns (3) and (4), or the two figures in one of these columns, in Table 4]. However, in $\mathrm{Cml}^{\mathrm{R}} \mathrm{SCPI}^{+} \times \mathrm{Cml}^{\mathrm{s}} \mathrm{SCPI}^{-}$crosses, the $\mathrm{Cml}^{\mathrm{s}}$ parental phenotype was always in a small minority and considerable imbalance was also often encountered in $\mathrm{SCPI}^{-} \times$ $\mathrm{SCPI}^{-}$crosses, even between pairs of $\mathrm{Cml}^{\mathrm{R}}$ strains.

It is apparent from column (I) in Table 4 that there is no large-scale 'infection' of the $\mathrm{Cml}^{\mathrm{s}}$ parent by $\mathrm{Cml}^{\mathrm{R}}$ in $\mathrm{SCP}_{1}{ }^{-} \times \mathrm{SCPI}^{-}$crosses: transfer frequencies of $\mathrm{Cml}^{\mathrm{R}}$ were in the order of $\mathrm{IO}^{-3}$ to $\mathrm{IO}^{-5}$. In the unbalanced $\mathrm{SCPI}^{+} \times \mathrm{SCPI}^{-}$crosses, they were higher: up to $4 \%$. As seen in column (2), the ratio of $\mathrm{Cml}^{\mathrm{R}}$ transfer to recombination was highly variable, ranging from 2700 to 0.2 . The fertility of crosses was also variable [columns (3) and (4)] but careful consideration of fertility in relation to the balance of the parental phenotypes suggust that in $\mathrm{SCPI}^{-} \times \mathrm{SCPI}^{-}$crosses the $\mathrm{Cml}$ status had no significant influence on fertility, $\mathrm{Cml}^{\mathrm{R}} \times \mathrm{Cml}^{\mathrm{s}}, \mathrm{Cml}^{\mathrm{R}} \times \mathrm{Cml}^{\mathrm{R}}$ and $\mathrm{Cml}^{\mathrm{s}} \times \mathrm{Cml}^{\mathrm{s}}$ crosses having similar ranges of 


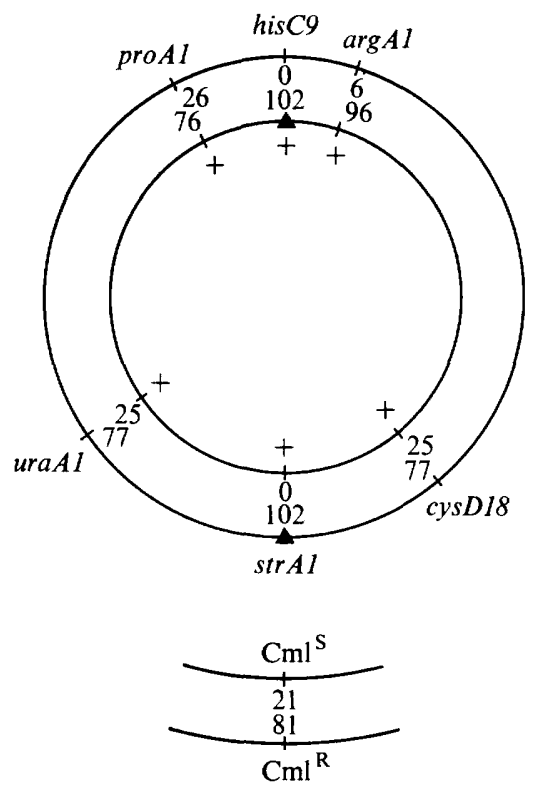

\begin{tabular}{c|cc} 
& ura $^{+}$ & ura \\
\hline $\mathrm{Cml}^{\mathrm{R}}$ & 14 & 67 \\
$\mathrm{Cml}^{\mathrm{S}}$ & 11 & 10 \\
& cys & cys \\
\hline $\mathrm{Cml}^{\mathrm{R}}$ & 14 & 67 \\
$\mathrm{Cml}^{\mathrm{S}}$ & 11 & 10
\end{tabular}

Fig. I. Results of a cross between $\mathrm{Cml}^{\mathrm{R}}$ strain $\mathrm{I} 258$ (outer circle) and $\mathrm{Cml}^{\mathrm{S}}$ strain $\mathrm{A} 3(2) / \mathrm{I}$ (inner circle). Recombinants inheriting his $C^{+}$and str $A I$ (indicated by triangles) were selected and classified for non-selected markers. Allele ratios indicate possible map positions for $\mathrm{Cml}$ between $c y s D$ and $\operatorname{str} A$ or between $\operatorname{str} A$ and $u r a A$. Tests of independence between the segregation of $\mathrm{Cml}$ and either ura or cys exclude both map positions.

fertility values. The highest apparent fertility was seen in unbalanced crosses when recombinants were expressed as a proportion of the minority parent.

\section{Attempts to map the $\mathrm{Cml}^{\mathrm{s}}$ character}

Crosses were made between multiply marked NF strain 1258 (proAI hisC9 $\arg A I$ cys DI8 uraAI strAI) and a series of $\mathrm{Cml}^{\mathrm{s}}$ derivatives of $\mathrm{A3}(2)$ and $\mathrm{A332}$, with selection for the diametrically opposed markers his $C^{+}$and $s t r A I$. This experimental design is efficient for preliminary mapping (Hopwood \& Chater, 1974). The allele ratio for the unknown marker (in this case $\mathrm{Cml}$ ) is considered in relation to those of the known non-selected markers, to give two alternative map positions for $\mathrm{Cml}$. These are evaluated by tabulating the segregation of $\mathrm{Cml}^{\mathrm{R}}$ versus $\mathrm{Cml}^{\mathrm{s}}$ in relation to that of the non-selected marker that would be closest to $\mathrm{Cml}$ in each of its possible positions. For all chromosomal markers that have been studied to date in $S$. coelicolor this procedure has yielded a map position which was compatible with the data and which was confirmed in subsequent crosses. In the case of the $\mathrm{Cml}^{\mathrm{s}}$ variants, however, the segregation data were incompatible with a map location.

An example from a series of crosses of strain I258 with four different $\mathrm{Cml}^{\mathrm{s}}$ derivatives of $\mathrm{A3}(2)$ is shown in Fig. I. On allele ratios, $\mathrm{Cml}$ could have mapped in either of the intervals defined by $c y s D, \operatorname{str} A$ and $u r a A$. With a location in the interval $\operatorname{str} A-\operatorname{cys} D$ the $\mathrm{Cml}^{\mathrm{s}}$ cys $D_{I} 8$ class should have been rare, as a multiple crossover class; for the interval strA-uraA, $\mathrm{Cml}^{\mathrm{s}}$ uraAI should have been rare. In fact, half the $\mathrm{Cml}^{\mathrm{s}}$ segregants carried cysDI 8 and the same proportion carried $u r a A I$. Thus neither map position was compatible with the data.

Five different $\mathrm{Cml}^{\mathrm{s}}$ derivatives of $\mathrm{A332}$ were crossed with strain 1258 ; an example is shown in Fig. $2(a)$. In each cross, only $\mathrm{I}$ to $5 \%$ of recombinants were $\mathrm{Cm}^{\mathrm{s}}$; this result alone 
(a)
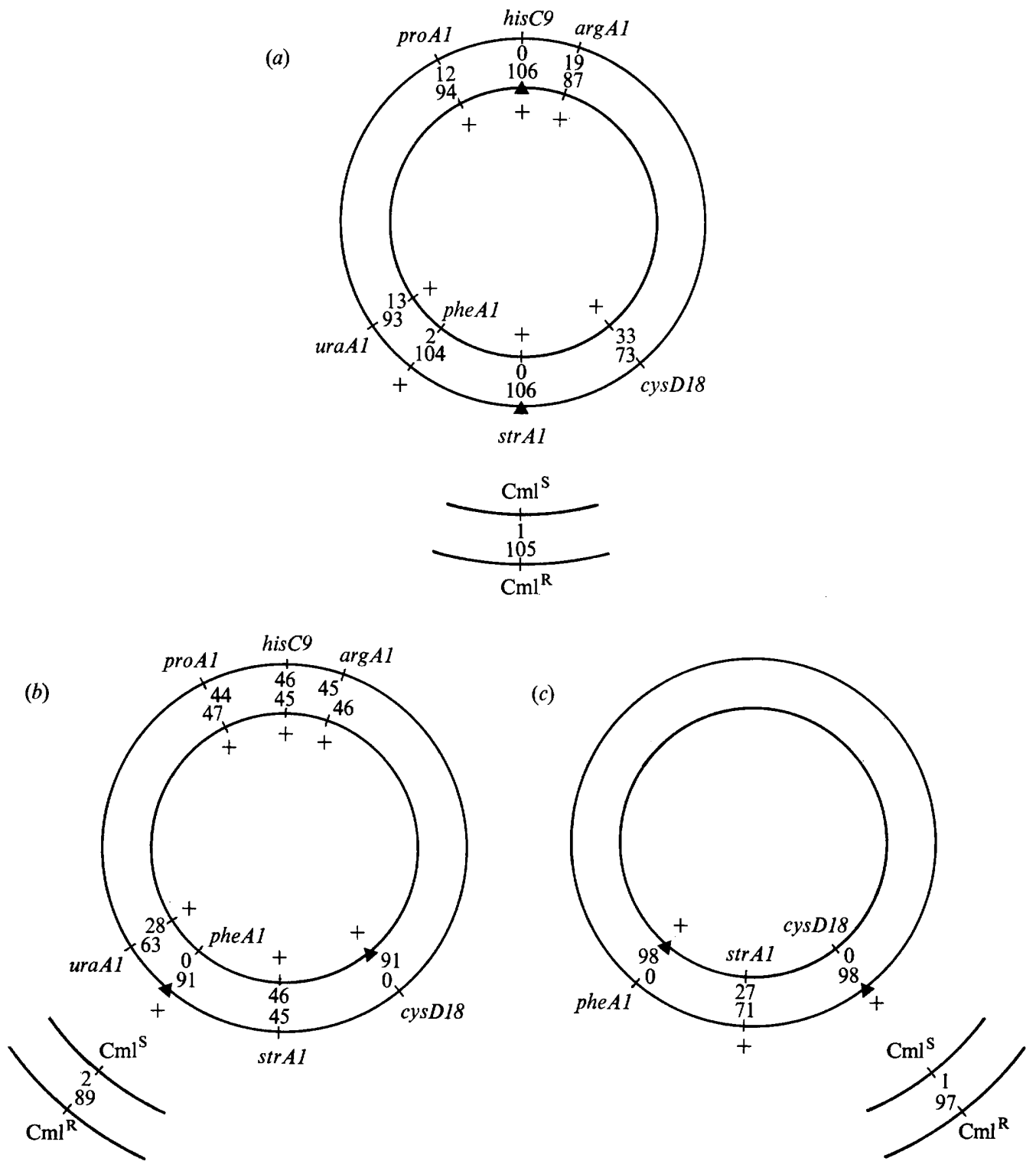

Fig. 2. Results of crosses between: (a), (b) strain $1258\left(\mathrm{Cml}^{\mathrm{R}}\right)$ and strain $\mathrm{A} 332 / 5\left(\mathrm{Cml}^{\mathrm{S}}\right) ;(c)$ strain A332 $\left(\mathrm{Cml}^{\mathrm{R}}\right)$ and strain $2552\left(\mathrm{Cml}^{\mathrm{S}}\right)$. See legend to Fig. I for explanation.

could have indicated a map location close to $\operatorname{str} A \mathrm{r}$, and the small proportion of $\mathrm{Cml}^{\mathrm{s}}$ progeny made it difficult to exclude a position in either of the two intervals defined by $c y s D$, str $A$ and $u r a A$. Therefore further selections from the same crosses, and further crosses involving $\mathrm{Cm}^{\mathrm{s}}$ recombinants from the first crosses, were made. Pairs of crosses with phe $A^{+}$cys $D^{+}$selection and reversed coupling of $\mathrm{Cml}^{\mathrm{s}} / \mathrm{Cml}^{\mathrm{R}}$ excluded a unique map location since each cross was incompatible with the location indicated by the other: the data of Fig. $2(b)$ indicate close linkage with phe $A$ and exclude close linkage with cys $D$, while in Fig. $2(c)$ the indications are reversed. 


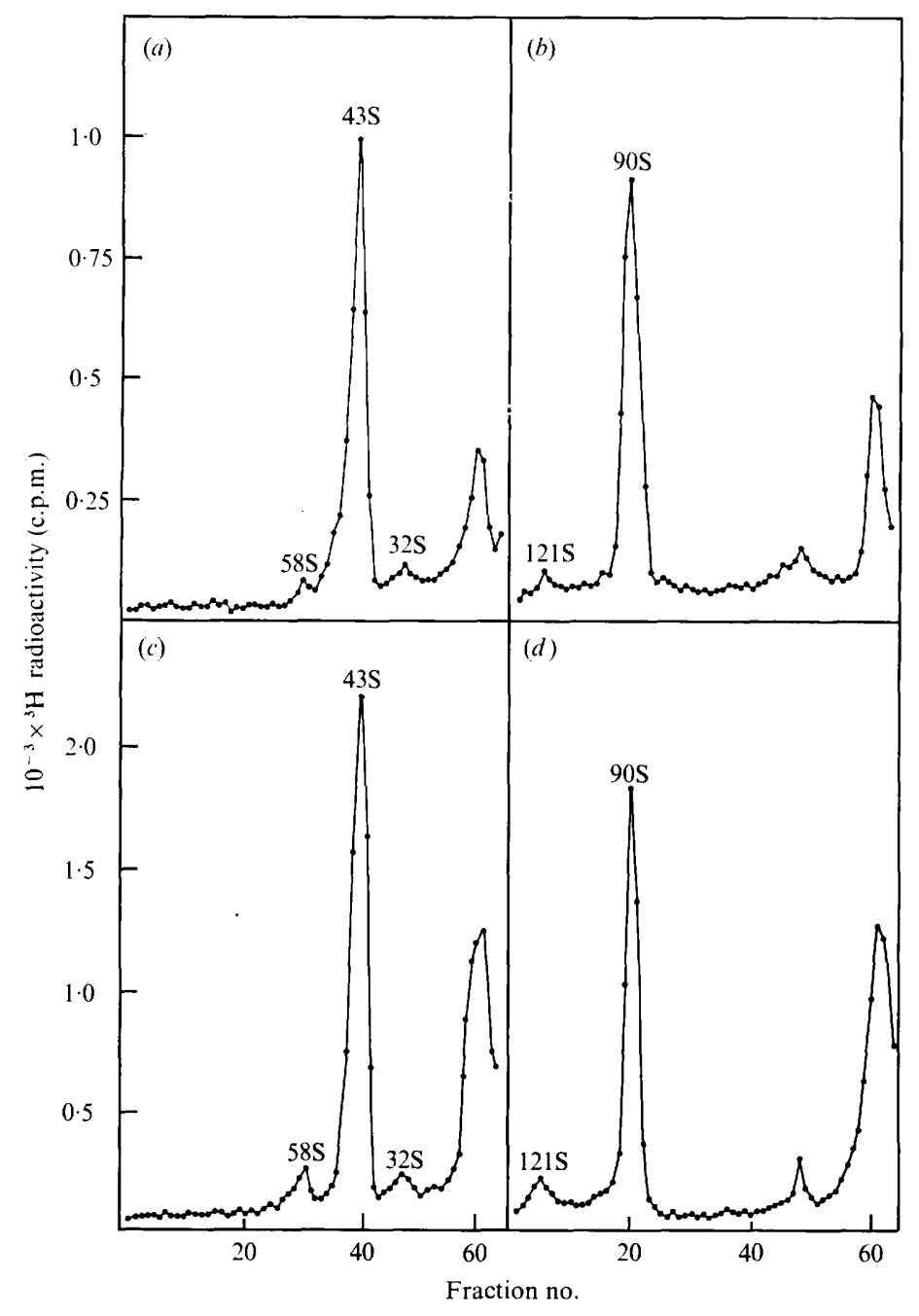

Fig. 3. Sedimentation profiles of $\left[{ }^{3} \mathrm{H}\right]$ thymidine-labelled DNA isolated from strains $1098 / 3(a, b)$ and $1098(c, d)$ in 5 to $20 \%$ sucrose gradients. The neutral gradients $(a, c)$ contained $0.03 \mathrm{M}$-Tris, $0.005 \mathrm{M}$-EDTA and $0.05 \mathrm{M}-\mathrm{NaCl}$, and were centrifuged for $45 \mathrm{~min}$ at $45000 \mathrm{rev} . \mathrm{min}^{-1}$ at $20^{\circ} \mathrm{C}$ in an SW 50.I rotor in a Beckman L2-65B centrifuge. The alkaline gradients $(b, d)$ contained in addition $0.2 \mathrm{M}-\mathrm{NaOH}$ and $0.7 \mathrm{M}-\mathrm{NaCl}$ and were centrifuged for $38 \mathrm{~min}$.

The conclusion is clear that none of the nine $\mathrm{Cml}^{\mathrm{s}}$ variants studied could be assigned to a unique chromosomal map location.

\section{Comparison of c.c.c. DNA from $\mathrm{Cml}^{\mathrm{R}}$ and $\mathrm{Cml}^{\mathrm{s}}$ cultures}

The major species of c.c.c. DNA isolated from a number of $\mathrm{Cml}^{\mathrm{R}} S$. coelicolor $\mathrm{A3}$ (2) strains of $\mathrm{NF}, \mathrm{SCPI}^{+}$and $\mathrm{SCPI}^{-}$fertility type has previously been found to have sedimentation values of $43 \mathrm{~S}$ and $90 \mathrm{~S}$ in neutral and alkaline conditions respectively, with a minor species of 58S and $12 \mathrm{IS}$ respectively (Schrempf et al., I975; and unpublished results). These values were determined by comparison with ColEr, which has equivalent sedimentation values of $23 \mathrm{~S}$ and $48 \mathrm{~S}$ respectively. A species corresponding to the open circular form of the 


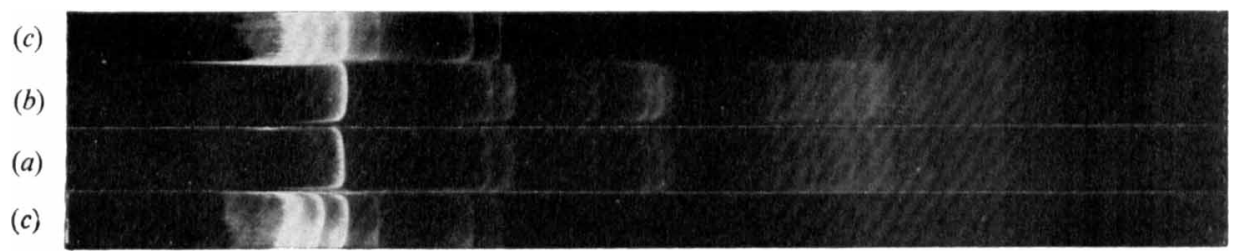

Fig. 4. Agarose (I.4\%, w/v) gel electrophoresis of Sall restriction endonuclease digests of $\mathrm{SCP}_{3}$ from strains $1098(a)$ and A332/I $(b)$. HindIII digests of phage $\lambda$ DNA (c), used as standards, had fragments with the following sizes (Mdaltons): $14 \cdot 5,6 \cdot 2,4 \cdot 2,2 \cdot 8,1 \cdot 6, \mathrm{I} \cdot 4$ and $0 \cdot 3$. Electrophoresis was from left to right as printed.

smaller $(43 \mathrm{~S})$ plasmid has also been observed with a sedimentation value at neutral $\mathrm{pH}$ of $32 \mathrm{~S}$. The smaller species of c.c.c. DNA corresponds to a plasmid with a molecular weight of $18.5 \times 10^{6}$ (Kupersztock-Portnoy, Miklos \& Helinski, 1974) which has been referred to as $\mathrm{SCP}_{3}$ (unpublished results) or as $\mathrm{pHS}$ ( $\mathrm{H}$. Schrempf, personal communication). The larger species appears to represent a dimer of $\mathrm{SCP}_{3}$; endonuclease digestion of c.c.c. DNA containing both species yields an identical pattern to that produced by digestion of the smaller species alone.

The transition from $\mathrm{Cml}^{\mathrm{R}}$ to $\mathrm{Cml}^{\mathrm{s}}$ might have been due to some change in $\mathrm{SCP}_{3}$, perhaps involving detectable loss or addition of DNA to the autonomous plasmid. To investigate this possibility ${ }^{3} \mathrm{H}$-labelled c.c.c. DNA was isolated from strains I098, A332, I098/I, I098/3, $\mathrm{A} 332 / \mathrm{I}$ and $\mathrm{A332} / 3$ and characterized by sedimentation in sucrose gradients. All strains exhibited identical sedimentation profiles (see Fig. 3 for examples). The radioactive material at the top of the gradients was residual chromosomal DNA. The $43 \mathrm{~S}, 58 \mathrm{~S}$ and $32 \mathrm{~S}$ species were observed in all neutral gradients. Thus the change from chloramphenicol resistance to sensitivity did not appear to result from loss of $\mathrm{SCP}_{3}$ or to any gross change in its size. However, our methods would not have detected changes in its molecular weight of less than about $\mathrm{I} \times \mathrm{IO}^{6}$ and therefore they did not eliminate the possibility that an insertion sequence might control expression of $\mathrm{SCP}_{3}$-borne chloramphenicol resistance genes in a similar way to the control of tetracycline resistance by IS3 in the plasmid R6/R6-5 (Cohen \& Kopecko, 1976).

Endonuclease digestion could reveal a much smaller difference than sedimentation analysis. SalI was chosen since $\mathrm{SCP}_{3}$ contains many sites of cleavage by this enzyme (unpublished results) and Sall digests of $\mathrm{SCP}_{3}$ would allow detection of any changes in molecular weight from 200000 (for a change in the largest fragment produced by SalI digestion) down to as little as 20000 (for a change in one of the smaller fragments). Since the smallest well characterized insertion sequence has about 700 base pairs (about 500000 daltons) (Ohtsubo \& Ohtsubo, 1976) it should be possible to detect the presence or absence of a typical insertion sequence in the transition from chloramphenicol resistance to sensitivity by comparing Sall digests of $\mathrm{SCP}_{3}$ isolated from $\mathrm{Cml}^{\mathrm{R}}$ and $\mathrm{Cml}^{\mathrm{s}}$ strains. Unlabelled $\mathrm{SCP}_{3}$ prepared from strains 1098 and $\mathrm{A} 332 / \mathrm{I}$ by the large-scale method was digested with SalI and the digestion products were analysed by agarose gel electrophoresis. HindIII digests of phage $\lambda$ were used to provide standard markers. Identical fragment patterns were obtained for $\mathrm{SCP}_{3}$ isolated from the two strains (Fig. 4); microdensitometer tracings (not shown) confirmed their identity. It thus seems unlikely that the transition from $\mathrm{Cm}^{\mathrm{R}}$ to $\mathrm{Cml}^{\mathrm{s}}$ involves a change in $\mathrm{SCP}_{3}$. 


\section{DISCUSSION}

Streptomyces lividans 66 and an $\mathrm{SCP}^{+}$derivative (strain I04) of S. coelicolor A3(2) were found by Shaw \& Hopwood (1976) to lack chloramphenicol acetyltransferase, the enzyme responsible for chloramphenicol resistance determined by $\mathbf{R}$ factors in enteric bacteria and staphylococci and also by chromosomal genes in other bacteria (Shaw, I974). We tested other $\mathrm{A} 3(2)$ derivatives, including the $\mathrm{Cml}^{\mathrm{R}}$ strains referred to in this paper, and found they all lacked the acetylating enzyme. Moreover they failed to destroy the antimicrobial activity of chloramphenicol in the growth medium as determined by a microbiological test (Shaw \& Hopwood, 1976). Thus the chloramphenicol resistance that distinguishes the $\mathrm{Cml}^{\mathrm{R}}$ strains from their $\mathrm{Cml}^{\mathrm{s}}$ derivatives must depend on some mechanism other than destruction of the antibiotic in the growth medium. A test for cross-sensitivity of $\mathrm{Cml}^{\$}$ strains to 17 other antibiotics and synthetic antimicrobial agents, representing several chemical classes and modes of action, gave no clues, since no cross-sensitivity was revealed.

The frequent origin of $\mathrm{Cml}^{\mathrm{s}}$ variants from $\mathrm{Cml}^{\mathrm{R}}$ strains of $S$. coelicolor A3(2), particularly after u.v. irradiation, suggests there might be loss of an extra-chromosomal genetic element. However, reversion of the $\mathrm{Cml}^{\mathrm{s}}$ variants to strains with a phenotype indistinguishable from that of the original $\mathrm{Cml}^{R}$ strains, including the ability to give rise to $\mathrm{Cml}^{\mathrm{s}}$ variants again, is incompatible with such a permanent loss of genetic information. Conventional mutation of a chromosomal gene or genes is also excluded by the failure to map any $\mathrm{Cml}^{\mathrm{s}}$ variant to the chromosomal linkage group and by the tendency of the $\mathrm{Cml}^{\mathrm{R}}$ character to be transferred in crosses independently of chromosomal markers. The question of whether there was a consistent difference in chromosomal recombination frequency between crosses in which both, one or neither parent was $\mathrm{Cml}^{\mathrm{s}}$ is complicated by the effects of the 'balance' of the two parental phenotypes coming from a cross, unbalanced crosses having very high apparent recombination frequencies when expressed as a proportion of the minority parental count. Certainly $\mathrm{Cml}^{\mathrm{s}} \times \mathrm{Cml}^{\mathrm{s}}$ crosses were not reduced in fertility, and any tendency for $\mathrm{Cml}^{\mathrm{R}} \times \mathrm{Cml}^{\mathrm{s}}$ to be more fertile than $\mathrm{Cml}^{\mathrm{R}} \times \mathrm{Cml}^{\mathrm{R}}$ crosses was at most marginal. Therefore the $\mathrm{Cml}^{\mathrm{R}} / \mathrm{Cml}^{\mathrm{s}}$ difference does not appear to be associated with a change in the activity of a sex factor.

The Cml status of a strain did not depend on the presence or absence of the SCPI sex factor since strains of $\mathrm{SCPI}^{+}, \mathrm{SCP}_{\mathrm{I}^{-}}$or NF (integrated SCPI) type (Hopwood et al., I973; Hopwood \& Wright, I976) had identical chloramphenicol resistance and gave rise to $\mathrm{Cml}^{\mathrm{s}}$ variants at a similar frequency. The $\mathrm{SCP}_{3}$ (pHSI) plasmid, which is so far of unknown function, might have been concerned in the $\mathrm{Cml}$ character. This possibility was made less likely by the finding that $S$. lividans 66 , which gave rise to $\mathrm{Cml}^{\mathrm{s}}$ variants at a similar frequency to $S$. coelicolor A3(2), did not yield this plasmid DNA. The finding that $\mathrm{Cml}^{\mathrm{R}}$ and $\mathrm{Cml}^{\mathrm{s}}$ derivatives of $S$. coelicolor A3(2) had c.c.c. DNA of indistinguishable molecular weight and apparently identical restriction endonuclease pattern makes it very unlikely that $\mathrm{SCP}_{3}$ is involved in the $\mathrm{Cml}$ phenotype; any change in it associated with the $\mathrm{Cml}^{\mathrm{R}}$ to $\mathrm{Cml}^{\mathrm{s}}$ transition would have had to be very small.

Recently a sex factor, $\mathrm{SCP}_{2}$ was postulated (unpublished results), which was identified by the origin of variants of $\mathrm{SCPI}^{-}$strains with an enhanced fertility towards normal $\mathrm{SCPI}^{-}$ strains. The increased fertility shown by such variants is 'infectious' in crosses with $\mathrm{SCPI}^{-}$ strains. It is not yet known whether $\mathrm{SCP}_{2}$ is responsible for all of the recombination normally found in $\mathrm{SCPI}_{I^{-}} \times \mathrm{SCP}_{I^{-}}$crosses. In crosses involving such variants, and of differing $\mathrm{Cml}$ status, the variant fertility character was transferred independently of $\mathrm{Cml}$ (Bibb, unpublished results). Thus $\mathrm{SCP}_{2}$, like $\mathrm{SCP}_{1}$ and $\mathrm{SCP}_{3}$, does not appear to be directly involved in the $\mathrm{Cml}$ phenotype. 
The frequency of $\mathrm{Cml}^{\mathrm{R}}$ progeny in crosses of pairs of $\mathrm{Cml}^{\mathrm{s}}$ variants of independent origin was not higher than the reversion rate of individual $\mathrm{Cml}^{\mathrm{s}}$ variants. This finding is compatible with the notion that $\mathrm{Cm}^{\mathrm{s}}$ variants represent a single genetic class, although the number of pairwise crosses between different $\mathrm{Cm}^{\mathrm{s}}$ strains was not large.

The reversibility of the change between $\mathrm{Cml}^{\mathrm{R}}$ and $\mathrm{Cml}^{\mathrm{s}}$ and the failure to define a unique chromosomal map location for the $\mathrm{Cml}^{\mathrm{R}} / \mathrm{Cml}^{\mathrm{s}}$ difference are suggestive of the involvement of some kind of transposition event, with certain features in common with recently described phenomena in the Enterobacteriaceae (Cohen \& Kopecko, 1976). Excision and re-insertion elsewhere in the genome of an element involved in the $\mathrm{Cml}$ phenotype might have given rise to frequent auxotrophic mutations, as in Salmonella typhimurium (Kleckner et al., 1975), but none were found in a limited study. In any case it seems unlikely that our results could be explained by the existence of one or more chromosomal genes subject to insertional inactivation and of fixed position, or even of variable but exclusively chromosomal location, since insertional and transpositional events occurring at frequencies of a few per cent should not have obscured a map location for any particular $\mathrm{Cml}^{\mathrm{s}}$ variant. Unless such events were much more frequent in $\mathrm{Cml}^{\mathrm{R}} \times \mathrm{Cml}^{\mathrm{s}}$ crosses than the origin of $\mathrm{Cml}^{\mathrm{s}}$ variants in single $\mathrm{Cml}^{\mathrm{R}}$ cultures, it seems that some genetic element capable of continued extra-chromosomal existence may be involved in chloramphenicol resistance in $S$. coelicolor.

Note added in proof. Recent examination of genetically defined SCP2- isolates (see Discussion) by dye-buoyant centrifugation has failed to reveal c.c.c. DNA corresponding to $\mathrm{SCP}_{3}$. Re-infection of the $\mathrm{SCP}_{2}$ - isolates with $\mathrm{SCP}_{2}$ or its increased fertility variant is correlated with the reappearance of $\mathrm{SCP}_{3}$ c.c.c. DNA. We therefore postulate that the two plasmids, $\mathrm{SCP}_{2}$ and $\mathrm{SCP}_{3}$, defined by independent genetical and physical criteria respectively, are one and the same entity. We propose to use the designation SCP2 for this sex factor in future.

M.J.B. gratefully acknowledges a postgraduate studentship funded by the Upjohn Company, and R.F.F. one from the Science Research Council.

\section{REFERENCES}

Benveniste, R. \& Davies, J. (1973). Aminoglycoside antibiotic-inactivating enzymes in actinomycetes similar to those present in clinical isolates of antibiotic-resistant bacteria. Proceedings of the National Academy of Sciences of the United States of America 70, 2276-2280.

BÉRDY, J. (I974). Recent developments of antibiotic research and classification of antibiotics according to chemical structure. Advances in Applied Microbiology 18, 309-406.

Boronin, A. M. \& Sadovnikova, I. G. (1972). Elimination by acridine dyes of oxytetracycline resistance in Actinomyces rimosus. Genetika 8, 174-176.

Chater, K. F. \& Wilde, L. C. (1976). Restriction of a bacteriophage of Streptomyces albus G involving endonuclease Sall. Journal of Bacteriology 128, 644-650.

CoHEN, S. N. \& KopEcko, D. J. (1976). Structural evolution of bacterial plasmids: role of translocating genetic elements and DNA insertion sequences. Federation Proceedings 35, 203 I-2036.

FreEmAN, R. F. (1976). Studies of antibiotic resistance and production in Streptomyces. Ph.D. thesis, University of East Anglia, Norwich.

Freeman, R. F., BibB, M. J. \& Hopwood, D. A. (1976). CAT-independent extra-chromosomal chloramphenicol resistance in Streptomyces coelicolor A3(2). Proceedings of the Society for General Microbiology 3 , I 83-1 84 .

HAROLD, R. J. \& Hopwood, D. A. (1970). Ultraviolet-sensitive mutants of Streptomyces coelicolor. I. Phenotypic characterisation. Mutation Research 10, 427-438.

Hopwood, D. A. (1967). Genetic analysis and genome structure in Streptomyces coelicolor. Bacteriological Reviews 3r, 373-403.

Hopwood, D. A. \& CHATER, K. F. (1974). Streptomyces coelicolor. In Handbook of Genetics, vol. I, pp. 237255. Edited by R. C. King. New York and London: Plenum Press. 
Hopwood, D. A. \& WRIGHT, H. M. (I976). Interactions of the plasmid SCPI with the chromosome of Streptomyces coelicolor A3(2). In Second International Symposium on the Genetics of Industrial Microorganisms, pp. 607-6r9. Edited by K. D. Macdonald. London and New York: Academic Press.

Hopwood, D. A., Chater, K. F., Dowding, J. E. \& Vivian, A. (1973). Advances in Streptomyces coelicolor genetics. Bacteriological Reviews 37, 37I-405.

Humphreys, G. O., Willshaw, G. A. \& Anderson, E. S. (I975). A simple method for the preparation of large quantities of pure plasmid DNA. Biochimica et biophysica acta $\mathbf{3 8 3}, 457-473$.

Kirby, R., Wright, L. F. \& Hopwood, D. A. (1975). Plasmid determined antibiotic production and resistance in Streptomyces coelicolor. Nature, London 254, 265-267.

Kleckner, N., Chan, R. K., Tye, B.-K. \& Botstein, D. (I975). Mutagenesis by insertion of a drugresistance element carrying an inverted repetition. Journal of Molecular Biology 97, 56I-575.

Kupersztock-Portnoy, Y. M., Miklos, G. L. G. \& Helinski, D. R. (I974). Properties of the relaxation complexes of supercoiled deoxyribonucleic acid and protein of the R plasmids R64, R28K, and R6K. Journal of Bacteriology 120, 545-548.

Lomovskaya, N. D., Mkrtumian, N. M., Gostimskaya, N. L. \& Danilenko, V. N. (i972). Characterisation of temperate actinophage $\phi \mathrm{C}_{3} \mathrm{I}$ isolated from Streptomyces coelicolor A3(2). Journal of Virology $\mathbf{9}$, $258-262$.

Онтsuво, H. \& Oнтsuво, E. (1976). Isolation of inverted repeat sequences, including ISI, IS2, and IS3, in Escherichia coli plasmids. Proceedings of the National Academy of Sciences of the United States of America 73, 2316-2320.

Okanishi, M., Ohta, T. \& Umezawa, H. (1970). Possible control of formation of aerial mycelium and antibiotic production in Streptomyces by episomic factors. Journal of Antiobitics (Japan) 23, 45-47.

Schrempf, H., Bujard, H., Hopwood, D. A. \& Goebel, W. (1975). Isolation of covalently closed circular deoxyribonucleic acid from Streptomyces coelicolor A3(2). Journal of Bacteriology 121, 416-42 I.

SHAw, W. V. (1974). Genetics and enzymology of chloramphenicol resistance. Biochemical Society Transactions 2, 834-838.

Shaw, W. V. \& Hopwood, D. A. (1976). Chloramphenicol acetylation in Streptomyces. Journal of General Microbiology 94, 159-I 66.

VIVIAN, A. (I97I). Genetic control of fertility in Streptomyces coelicolor A3(2): plasmid involvement in the interconversion of UF and IF strains. Journal of General Microbiology 69, 353-364.

Wright, L. F. \& Hopwood, D. A. (1976). Identification of the antibiotic determined by the SCPI plasmid of Streptomyces coelicolor A3(2). Journal of General Microbiology 95, 96-106. 